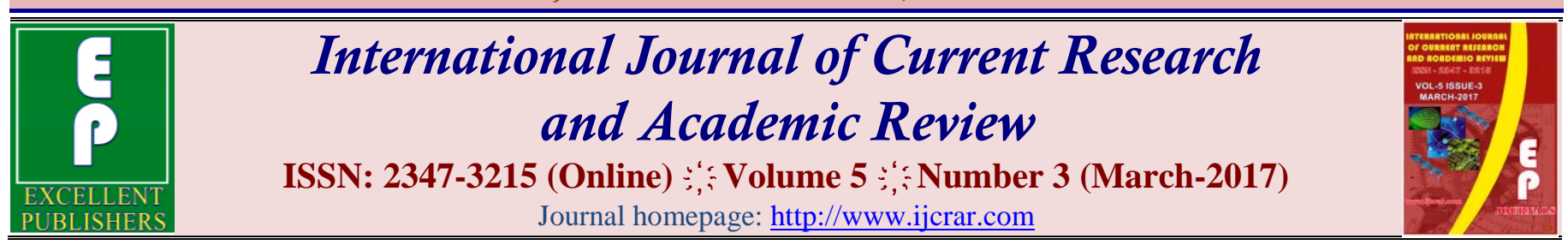

doi: $\underline{\text { https://doi.org/10.20546/ijcrar.2017.503.005 }}$

\title{
Comparative Analysis of Stomatal Type Swietenia macrophylla King and Polyalthia longifolia Bent and Hook. var. Pendula in Makassar, South Sulawesi, Indonesia
}

\author{
Elis Tambaru*
}

Department of Biology, Faculty of Mathematics and Natural Sciences, University of Hasanuddin, Tamalanrea 90245 , Makassar, Indonesia

*Corresponding author: eli.tambaru@yahoo.com

\begin{abstract}
The purpose of this research was to know comparative analysis of leaf stomatal trees Swietenia macrophylla King and Polyalthia longifolia Bent \& Hook. Var. Pendulain Makassar City. This research has been conducted in A.P. Pettarani Street and Industrial Area Makassar. This research used modification method acetonethen performed a descriptive analysis. The results showed that stomatal type of Swietenia macrophylla and Polyalthia longifolia is parasitic and phanerophor. The highest density of leaf stomatal on Swietenia macrophylla King is 877 stomata $\mathrm{mm}^{-2}$ in Industrial Area Makassar and the lowest density of stomatal on the leaf Polyalthia longifolia Bent \& Hook. var. Pendulais 411 stomata $\mathrm{mm}^{-2}$, in A.P. Pettarani Street.
\end{abstract}

\section{Article Info}

Accepted: 28 February 2017

Available Online: 20 March 2017

Keywords

Comparative, Stomatal Trees,

Makassar City.

\section{Introduction}

Green Open Space is a form of land use in urban areas that are intended for greening the city (Abril, 2009). Increased concentrations of $\mathrm{CO}_{2}$ in atmosphere will cause a rise in temperature of the earth, so occurred Greenhouse Effect. The growth response due to $\mathrm{CO}_{2}$ is too high above the threshold, can lead to changes in morphology, anatomy and biochemistry of plants (Singsaas et al., 2003), can also cause leaf stomata partially closed, thus reducing transpiration (Gohil et al., 2010). Vegetation must possess certain characteristics that can help overcome the problems associated with the environment.Urban vegetation serves to give an aesthetics, unifying space, minimize air pollution, produce oxygenand micro-climate amelioration (Grey and Deneke, 1978; Lovelli et al.,
2010; Zhao et al., 2009). Makassar is city center of various activitiessuch as the economy and education, so that the population is getting ever-growing.

The number of people in Makassar resulted in community activities is also increasing, it can be seen from density of vehicles on the roads.To balance $\mathrm{CO}_{2}$ emissionsneed to be coupled with greening trees in Makassar by planting various species of trees in accordance with the allotment of land. Based on the description above, so that the research of comparative analysis of stomatal type Swietenia macrophylla King and Bent \& Hook. var. Pendula in Makassar was conducted. 


\section{Materials and Methods}

\section{Plant materials}

Leaf of trees greening namely Swietenia macrophylla King and Polyalthia longifolia Bent \& Hook. var. Pendula.

\section{Stomatal analysis}

Leafof trees greening used in this research were selected characteristics from trees that look healthy and disease. Analysis of stomatal using a modified method of acetone (Tambaru et al., 2014), each leaf smeared with acetone for \pm 2 minutes, samples were placed on a glass object and observed under a binocular microscope with micrometer scale, then image taken using microscope Bino\& Photo.Observations stomatal characteristics used reference Nugroho et al., 2006; Sunarti et al., 2008; Pandey and Chandha, 1996; Agustini, 1999 and Kurnia, 2005 cit. Hidayat, 2009. Calculations for stomatal index (IS) based formula (Wilmer (1983) cit. Damayanti, 2007) as follows:

$$
\mathrm{IS}=\frac{S / L}{(S+E) / L} \times 100 \%
$$

whereby:

$\mathrm{S}=$ number of stomata

$\mathrm{E}=$ number of epidermal cells

$\mathrm{L}=$ unit leaf area

Stomatal analysis also do descriptively. This resarch was also measured of environmental factors as supporting data.

\section{Results and Discussion}

The results of analysis stomatal characteristics which grows in A.P. Pettarani Street (busiest streets and polluting vehicles) and Industrial Area Makassar (polluted factory) is shown in table 1 .

Type stomatal of Swietenia macrophylla and Polyalthia longifolia are parasitic, while both types of stomata in this research were found in Dicotyledoneae. Leaf stomatal in this class, the structure is spread on leaf epidermis tissue andkidney-shaped cells of stomata closing.Type of deployment stomatal Swietenia macrophylla and Polyalthia longifolia on the surface of adaxialwhere the number of stomata less than the abaxial surface.According to Pandey and Chandha (1996), type of stomata which are spread on both surfaces of leaves called potato type (Table 1). The number of stomata on adaxial surface less, it is a mechanism of adaptation trees to the terrestrial environment (Campbell et al., 2003), thus reducing transpiration (Larcher, 1995; Taiz and Zeiger, 2002).

Stomatal density of leaf Swietenia macrophylla highs above 500 stomata $\mathrm{mm}^{-2}$. Density of leaf stomatal Polyalthia longifolia including medium criteria with the number of leaf stomatal300-500 stomata $\mathrm{mm}^{-2}$. According Agustini (1999) and Kurnia (2005) cit Hidayat (2009), size of stomata length: long enough $(<20$ $\mathrm{m})$, length $(20-25 \mathrm{~m})$ and very long $(>25 \mathrm{~m})$. Stomatal density: low $\left(<300\right.$ stomata $\mathrm{mm}^{-2}$ ), medium (300-500 stomata $\mathrm{mm}^{-2)}$, and high (> 500 stomata $\mathrm{mm}^{-2)}$. The highest number of epidermal cells abaxial tree species Swietenia macrophylla as much as $3396 \mathrm{~mm}^{-2}$ epidermal cells is on site Industrial Area Makassar, the lowest on type Polyalthia longifolia is $1681 \mathrm{~mm}^{-2}$ epidermal cells on site Industrial Area Makassar (Table 1). The influence of environmental factors and type of plants can affect number of epidermis cells. Types of trees that grow in polluted environments has a number of epidermal cells leaves more than a less polluted, as well as the number of stomata less.

The measurements of environmental factors in A.P.Pettarani Street that is dust content 79.57-116.322 $\mu \mathrm{gN} / \mathrm{m}^{3}$, wind velocity $0.30-1.51 \mathrm{~m} / \mathrm{sec}$. Temperatures $30.80-38.70^{\circ} \mathrm{C}$, and humidity $30.67-56.33 \mathrm{RH} \%$. Industrial Area Makassar were dust content 36.793 $140.535 \mu \mathrm{gN} / \mathrm{m}^{3}$, wind velocity $0.56-2.25 \mathrm{~m} / \mathrm{sec}$. Temperatures $33.9-43.00^{\circ} \mathrm{C}$ and humidity 34.33 $51.00 \mathrm{RH} \%$. The number of leaf stomatal can be affected by location of a place to growand type of plant. It is supported by the results of this research, thatpolluted environmentlike on A.P. Pettarani Street and Industrial Area Makassar, density of leaf stomatal small amounts.

The reduced number of stomata on the leaf surface, can be caused by dust adsorbed on the surface of leaf, thus covering the stomatal. According to Gardner et al., (1985); Fitter and Hay (1981), on the leaf surface there are a number of stomata that serves as the $\mathrm{CO}_{2}$ diffusion when stomatal open. Absorption of $\mathrm{CO}_{2}$ into leaf tissue is physiologically related to the number of stomatal per unit leaf area. Damage leaf stomatal can be caused by dust particles adsorbed on the surface of leafthat entering through a gap stomata. 
Table.1 Stomatal characteristics based longitudinal cross-section leaf greening trees in A.P. Pettarani Street and industrial area Makassar

\begin{tabular}{|c|c|c|c|c|}
\hline \multirow[t]{2}{*}{ Characteristics } & \multicolumn{2}{|c|}{ Swietenia macrophylla } & \multicolumn{2}{|c|}{ Polyalthia longifolia } \\
\hline & $\mathrm{A}$ & B & A & B \\
\hline Location of stomatal & $\begin{array}{l}\text { adaxial and } \\
\text { abaxial }\end{array}$ & $\begin{array}{l}\text { adaxial and } \\
\text { abaxial }\end{array}$ & $\begin{array}{l}\text { Adaxial and } \\
\text { abaxial }\end{array}$ & $\begin{array}{l}\text { Adaxial and } \\
\text { abaxial }\end{array}$ \\
\hline Type stomatal & parasitic & parasitic & parasitic & parasitic \\
\hline Long stomatal & 16.8 to $21.6 \mu \mathrm{m}$ & $19.2 \mu \mathrm{m}$ & 24 to $26.4 \mu \mathrm{m}$ & 19.2 to $21.6 \mu \mathrm{m}$ \\
\hline Width of stomatal & 14.4 to $19.2 \mu \mathrm{m}$ & 16.8 to $19.2 \mu \mathrm{m}$ & 19.2 to $21.6 \mu \mathrm{m}$ & 14.4 to $16.8 \mu \mathrm{m}$ \\
\hline Stomatal Index & 19.16 to $22.57 \%$ & 19.32 to $21.36 \%$ & 14.49 to $16.94 \%$ & 19.69 to $23.04 \%$ \\
\hline Cell shape of closing stomatal & kidney-shaped & kidney-shaped & kidney-shaped & kidney-shaped \\
\hline The layout of the cell cover & Panerofor & Panerofor & Panerofor & Panerofor \\
\hline StomatalOpening & 7.2 to $9.6 \mu \mathrm{m}$ & 4.8 to $7.2 \mu \mathrm{m}$ & 4.8 to $7.2 \mu \mathrm{m}$ & 4.8 to $7.2 \mu \mathrm{m}$ \\
\hline The spread of stomatal & Irregular & Irregular & Irregular & Irregular \\
\hline Deployment Type of Stomatal & Type potato & Type potato & Type potato & Type potato \\
\hline
\end{tabular}

Description: (A) Location in A.P PettaraniStreet and (B) Location in Industrial Area Makassar.

Table.2 Comparison of leaf stomatal on location A.P. Pettarani Street and Makassar Industrial Estate

\begin{tabular}{lrrrr}
\hline \multirow{2}{*}{ Characteristics } & \multicolumn{2}{c}{ Swietenia macrophylla } & \multicolumn{2}{c}{ Polyalthia longifolia } \\
\cline { 2 - 5 } & \multicolumn{1}{c}{$\mathrm{A}$} & \multicolumn{1}{c}{$\mathrm{B}$} & $\mathrm{A}$ & \multicolumn{1}{c}{$\mathrm{B}$} \\
\hline Stomal Density Abaxial $\left(\mathrm{mm}^{-2)}\right.$ & 743 & 877 & 411 & 443 \\
Number of Cells Abaxial Epidermis $\left(\mathrm{mm}^{2)}\right.$ & 2876 & 3396 & 2183 & 1681 \\
Abaxial Stomatal Index (\%) & 20.480 & 20.497 & 15.880 & 20.943 \\
\hline
\end{tabular}

Description: (A) Location A.P. Pettarani Street and (B) Location Industrial Area Makassar.

Fig.1 Swietenia macrophylla (A) and Polyalthia longifolia (B); Tree (1), Stomatal Adaxial (2), and Stomata Abaxial (3). Stomata 400x magnification
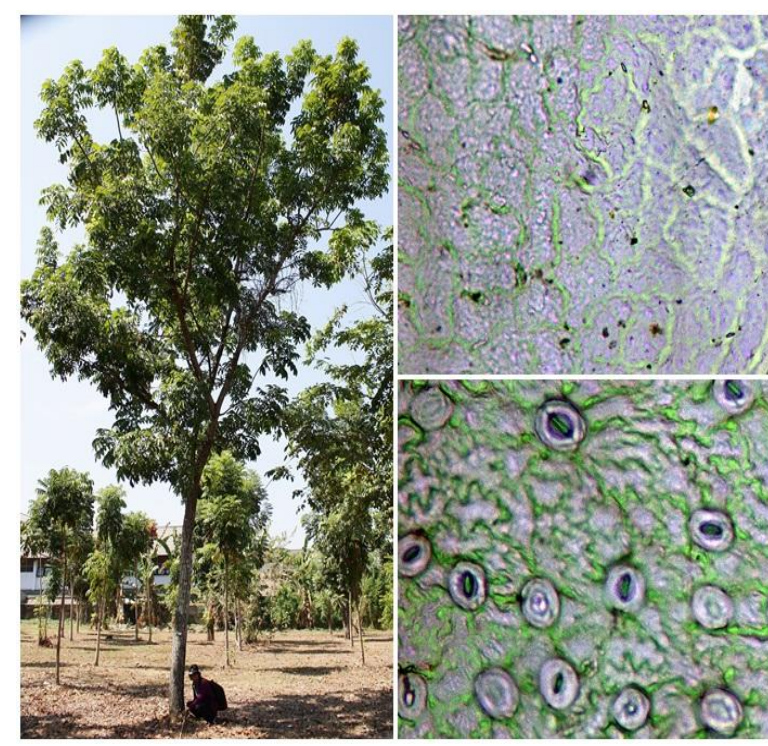

According Rantung (2006) dust particles entering into stomatal, can accumulate around the leaf tissue, causing

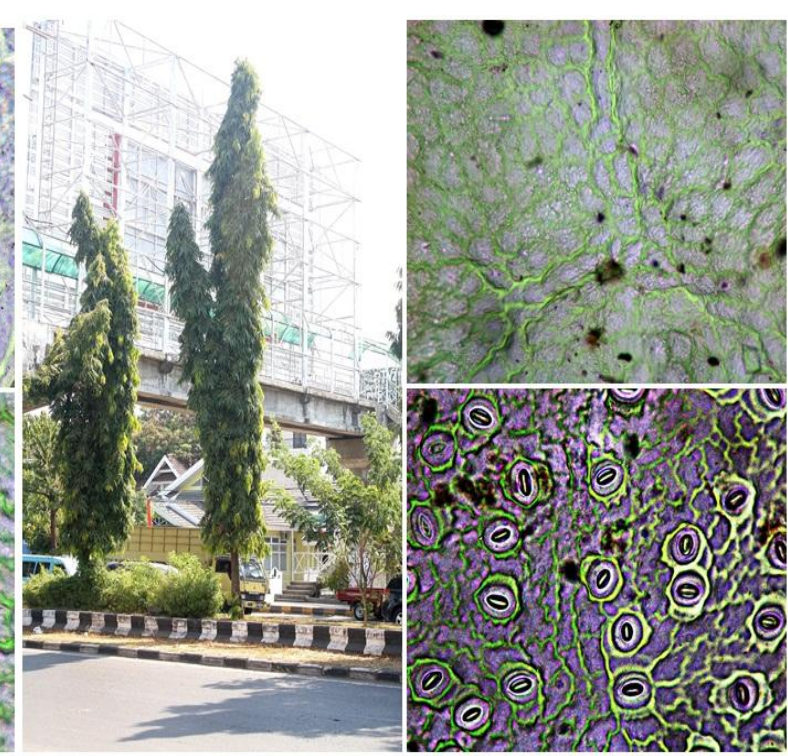

damage stomata, which in turn can inhibit absorption of $\mathrm{CO}_{2}$, growth and development of trees. 


\section{Conclusion}

The results showed that stomatal type of Swietenia macrophylla and Polyalthia longifolia is parasitic and phanerophor.The highest density of leaf stomatal on Swietenia macrophylla is 877 stomata $\mathrm{mm}^{-2}$ in Industrial Area Makassar and the lowest density of stomatalon the leaf Polyalthia longifolia Bent \& Hook. var. Pendulais 411 stomata $\mathrm{mm}^{-2}$, in A.P. Pettarani Street.

\section{Acknowledgements}

We thank Head of Environmental Agency, Makassar, for providing us with information of pollution in Makassar. We also thank Leadership of Industrial Area Makassar, Indonesia.

\section{References}

Abril, 2009. The Provision of Green Open Space (RTH) in Urban Area. http/google web. Accessed 6/5/2009.5: 33 $\mathrm{pm}$.

Campbell, N.A., Reece, J.B. and L.G. Mitchell. 2003. Biology, Fifth Edition-Volume 2. The Publisher, Jakarta, p. 309-310.

Damayanti, F. 2007. Chromosome Analysis and Anatomy Stomatal on Some Germplasm Banana (Musa sp.) Origin East Kalimantan. Bioscientiae, 4(2): 53-61.

Fitter, A.H. and R.K.M. Hay. 1981. Environmental Physiology of Plants. Published by Arrangement with Academic Press, Inc., (London) Ltd., pp.421.

Gardner, F.P., R.B. and R.L. Mitchell Pearce. 1985. Physiology of Crop Plants. The Iowa State University Press, pp. 1-73.

Gohil, H., M.J. Correl and T. Sinclair. 2010. Predicting the Effects of Gas Diffusivity on Photosynthesis and transpiration of Plants Grown Under Hypobaria. (Online)www.sciencedirect.com. 12 August 2010. The Department of Agricultural and Biological Engineering, University of Florida. Published by Elsevier Ltd.On Behalf of COSPAR.

Grey, G. and F. Deneke, 1978. Urban Forestry. Copy Editing was supervised by Eugene Patty, pp. 279.
Hidayat, S.R. 2009. Analysis of Stomatal Characteristics, Chlorophyll Content and Content of Heavy Metals in Leaves Trees Road Protective Region Lumpur Porong Sidoarjo. Faculty of Science and Technology, Islamic University of Malang, pp. 35-59.

Larcher, W. 1995. Plant Physiological Ecology Ecophysiology and Stress Physiology of Functional Groups. Third Edition. Springer-Verlag Berlin Heidelberg. Printed in Berlin, pp. 506.

Lovelli, A., M. Perniola, T. Tommaso, D. Ventrella, Moriondo M., and M. Amato, 2010. Effects of Rising Atmospheric $\mathrm{CO}_{2}$ on Crop Evapotranspiration in a Mediterranean Area. Agricultural Water Management Elsevier BV 97: 1287 -1292.

Nugroho, L.H., Purnomo and I. Sumardi. 2006. Structure and Development of Plants. Publisher Peneber Governmental. Jakarta, pp. 84-119.

Pandey, S.N. and A. Chandha. 1996. A Texbook of Botany Plant Anatomy and Economic Botany Volume III. Vikas Publishing House PVT LTD New Delhi, pp. 96103.

Rantung, J.L. 2006. Impact of Air Pollution at Angsana Tree (Pterocarpusindicus Willd.). Eugenia, 12(2): 167-172.

Singsaas, E.L., D.R. Ort and E.H. DeLucia. 2003. Effects of Elevated $\mathrm{CO}_{2}$ on Mesophyll Conductance and Its Consequences for interpreting photosynthetic Physiology. Plant, Cell and Environ., 27: 41-50.

Sunarti, S., Rugayah, E.F., Tihurun. 2008. Study Anatomy Leaf Types Averrhoa in Indonesia to Reinforce the Taxonomic Status. News Biol., 9(3): 253-257.

Taiz, L. and E. Zeiger. 2002. Plant Physiology. Third Edition. Sinauer Associates. Inc. Publishers, Sunderland, Massachusetts, pp. 111-192.

Tambaru, E., M.R. Umar, A.I. Latunra, and M. Sulaiman. 2014. The Role of Bamboo Betung Dendrocalamusasper (Schult f.) Backer for Absorbing Carbon Dioxide in the North Toraja District. $J$. Natural and Environ. Sci., 5(10): 52-57.

Zhao, M., Z.K., F.J. Escobedo and J. Gao. 2009. Impacts of Urban Forests on industrial Offsetting Carbon Emissions from Energy Use in Hangzhou, China. Elevier Ltd. All Rights reserved. J. Environ. Management, 91: 807-813.

\section{How to cite this article:}

Elis Tambaru. 2017. Comparative Analysis of Stomatal Type Swietenia macrophylla King and Polyalthia longifolia Bent and Hook. var. Pendula in Makassar, South Sulawesi, Indonesia. Int.J.Curr.Res.Aca.Rev. 5(3), 31-34.

doi: https://doi.org/10.20546/ijcrar.2017.503.005 